\title{
KEWAJIBAN BIDAN DALAM MENANGGULANGI KEMATIAN IBU DAN KEMATIAN BAYI DI HUBUNGKAN DENGAN UNDANG-UNDANG KESEHATAN NOMOR 36 TAHUN 2009 \\ TENTANG KESEHATAN JUNCTO KEPUTUSAN GUBERNUR JAWA BARAT NOMOR 441.8/KEP.1076-DINKES/2014 TENTANG TIM KOORDINASI PROGRAM PENYELAMATAN IBU DAN BAYI BARU LAHIR
}

\author{
Sartika Dewi, Program Studi Magister Ilmu Hukum \\ Universitas Buana Perjuangan Karawang \\ Email : sartikadewi.211290@yahoo.com
}

\begin{abstract}
ABSTRAK
Bidan memberikan pelayanan kebidanan yang berkesinambungan dan paripurna, berfokus pada aspek pencegahan, promosi dengan berlandasan kemitraan dan pemberdayaan masyarakat bersama-sama dengan tenaga kesehatan lainnya untuk senantiasa siap melayani siapa saja yang membutuhkan, kapan dan dimanapun dia berada. Kementrian Kesehatan telah mengembangkan serangkaian model terobosan berbasis tekhnologi informasi dan komunikasi guna meningkatkan kualitas pelayanan komplikasi kegawatdaruratan ibu dan bayi serta meningkatkan efisiensi dan efektivitas sistem rujukan mengingat UU No 36 tahun 2009 tentang Kesehatan. Kementrian Kesehatan memberikan terobosan terbaru dalam penangananan AKI dan AKB dengan meluncurkan program EMAS (expanding, maternal, and newborn survival). Sijariemas Kabupaten Karawang adalah sistem informasi komunikasi jejaring rujukan gawat darurat ibu dan bayi baru lahir, yang telah diintegrasikan dengan karawang sehat dan KEPGUB No 441.8/Kep.1076-Dinkes/2014 Tentang Tim Koordinasi Program Penyelamatan Ibu dan Bayi Baru Lahir.
\end{abstract}

Kata kunci : Kematian Ibu (AKI) dan Kematian Bayi (AKB), Program SijariEMAS

\section{ABSTRCAK}

Midwives provide continuous midwifery services and plenary, focusing on the aspects of prevention, promotion to partnership and empowerment grounded together with other health professionals are always ready to serve anyone in need, whenever and wherever he is. The Ministry of Health has developed a series of models based breakthrough information and communication technology in order to improve the quality of emergency services maternal and infant complications and to improve the efficiency and effectiveness of referral systems considering Act No. 36 of 2009 on Health. The Ministry of Health provides the latest breakthroughs in the handling of this MMR and IMR by launching a program GOLD (expanding, maternal, and newborn survival). Sijariemas Karawang is the communication of information 
systems emergency referral network of mothers and newborns, which has been integrated with healthy karawang and KEPGUB No. 441.8 / Kep.1076-DHO / 2014 About the Program Coordination Team Rescue Mother and Newborn

Keywords: Maternal Mortality (MMR) and Infant Mortality Rate (IMR), EMAS Karawang 


\section{PENDAHULUAN}

\section{A. Latar Belakang}

Kesehatan merupakan kebutuhan pokok manusia, karena kesehatan merupakan modal utama manusia dalam menjalankan aktifitas sehari-hari. Melaksanakan upaya kesehatan yang semaksimal mungkin bagi rakyat adalah tugas dari pemerintah bersama-sama rakyat yang bahu membahu menyelenggarakan upaya kesehatan agar tercapai derajat kesehatan yang optimal. (Safitri Hariani 2005:1)

Upaya peningkatan kualitas hidup manusia di bidang kesehatan, merupakan suatu uasaha yang sangat luas dan menyeluruh, usaha tersebut meliputi peningkatan kesehatan masyarakat baik fisik maupun non fisik. Di dalam sistem kesehatan nasional disebutkan, kesehatan menyangkut semua segi kehidupan yang ruang lingkup dan jangkauannya sangat luas dan kompleks. Menurut Undang-Undang No 36 Tahun 2009 tentang Kesehatan, Pasal 1 Ayat (1) "kesehatan adalah keadaan sehat, baik secara fisik, mental, spiritual maupun sosial yang memungkinkan setiap orang untuk hidup produktif secara sosial dan ekonomis (Yusuf Sofie, 2009:134)

Indikator kesejahteraan suatu bangsa ditentukan oleh kesehatan, pendidikan, dan ekonomi. Upaya yang dilakukan di bidang kesehatan adalah dengan meningkatk 
Umur Harapan Hidup (UHH) dengan cara menurunkan Angka Kematian Ibu (AKI) dan Angka Kematian Bayi (AKB), Angka Kematian Balita (AKABA), Angka Kematian Kasar (AKK).

Dalam memperbaiki kesehatan ibu, bayi baru lahir dan anak telah menjadi prioritas utama dari pemerintah, bahkan sebelum Millenium Development Goal's (MDGs) 2015 ditetapkan. Angka kematian ibu (AKI) dan Angka Kematian Bayi (AKB) merupakan salah satu indikator utama derajat kesehatan suatu negara. AKI dan AKB juga mengindikasikan kemampuan dan kualitas pelayanan kesehatan, kapasitas pelayanan kesehatan, kualitas pendidikan dan pengetahuan masyarakat, kualitas kesehatan lingkungan, sosial budaya serta hambatan dalam memperoleh akses terhadap pelayanan kesehatan (www.Depkes.go.id)

Dalam rangka mendukung program pemerintah RI dalam upaya untuk mempercepat penurunan $\mathrm{AKI}$ dan $\mathrm{AKB}$ sesuai dengan target MDGs 4 dan 5 maka perlu meningkatkan penyediaan akses terhadap pelayanan kesehatan dan pengembangan pelayanan kesehatan berbasis masyarakat. Sehubungan dengan hal tersebut di dalam Undang-Undang Kesehatan No 36 tahun 2009 tentang Kesehatan bagian kedua tentang fasilitas pelayanan kesehatan mengkaji bahwa pelayanan kesehatan, menurut jenis pelayanan kesehatan terdiri atas : pelayanan kesehatan perseorangan dan pelayanan kesehatan masyarakat. Pelayanan kesehatan tersebut dilaksanakan oleh pihak pemerintah, pemerintah daerah dan swasta.

Pelayanan kebidanan yang bermutu adalah pelayanan yang berdasarkan standar, dan kode etik bidan serta hubungan interpersonal yang adekuat. Sesuai dengan UU 
No 36 tahun 2009 tentang Kesehatan Pasal 24 Ayat (1) bahwa "tenaga kesehatan harus memenuhi ketentuan kode etik, standar profesi, hak pengguna pelayanan kesehatahan, standar pelayanan dan standar prosedur operasional".

Bidan sebagai salah satu tenaga utama dalam percepatan penurunan AKI \& AKB baru lahir, dituntut untuk mengantisipasi perubahan tersebut, sehingga pelayanan yang diberikan lebih bermutu, optimal dan mencapai tujuan yang diharapkan. Seiring perkembangan dunia medis yang sedemikian pesatnya, maka pelayanan kebidanan dituntut untuk bisa mengikuti dan pengimbangi perkembangan pelayanan medis dan kesehatan lainnya. (Estiwidani, Meilani, Widyasih, Widyastuti 2008:32)

Dalam memberikan pelayanan kebidanan yang sesuai dengan standar, bidan menggunakan tolak ukur Standar Pelayanan Kebidanan yang telah ditetapkan oleh Departemen Kesehatan. Pengertian bidan menurut ICM (International Confederation Of Midwives) Bidan adalah seseorang yang telah mengikuti program pendidikan bidan yang diakui di negaranya, telah lulus dari pendidikan tersebut, serta memenuhi kualifikasi untuk didaftar (register) dan atau memiliki ijin yang sah (lisensi) untuk melakukan praktik kebidanan.

Dalam memperoleh pemeliharaan kesehatan ibu dan anak akan melibatkan tenaga kesehatana khususnya bidan, karena pelayanan kebidanan erat hubungannya dengan kesehatan wanita, sejak remaja, masa calon pengantin, masa kehamilan, persalinan fase interval (fase diantara dua kehamilan) dan menopause serta memantau tumbuh kembang balita serta anak pra sekolah.(Veronica Komalawati 2009:40) 
Hubungan anatara bidan dan kliennya tidak selamanya berjalan dengan lancar dan mulus. Adakalanya hubungan diantara mereka mengalami suatu krisis berupa ketidakpuasan klien pada pelayanan kesehatan yang dberikan. Persoalannya, masyarakat yang tidak memahami seluk beluk kedokteran cenderung lebih melihat perawatan dari hasilnya. Padahala hasil perawatan tidak dapat diprediksi secara pasti, seorang bidan dalam praktiknya hanya memberikan jaminan proses yang sebaik mungkin, serta tidak sama sekali menjanjikan hasil. dalam melaksanakan tugas kebidanan yang penuh dengan risiko ini seorang bidan tidak dpat menghindarkan diri dari kekuasaan Allah, karena kemungkinan klien menjadi cacat atau meninggal dunia setalah ditangani,walaupun bidan tersebut telah melakukan tugasnya sesuai dengan Standar Pelayanan Kebidanan. (Soewono 2005:125)

Jika terjadi kesalahan tenaga kesehatan dalam melakukan perawatan, di mana tindakan itu mengakibatkan timbulnya kerugian bagi pasien, tindakan tersebut mengandung aspek pertanggungjawaban di bidang hukum administrasi. Aspek hukum adminis-tratisnya di sini dinilai dari sudut kewenangannya, yaitu : apakah tenaga kesehatan yang bersangkutan berwenang atau tidak melakukan perawatan? Berdasarkan pada hal di atas tersebut, dapat ditarik kesimpulan bahwa untuk melakukan sesuatu pekerjaan sebagai tenaga kesehatan diperlukan sebagai persyaratannya, salah satu persyaratannya yang paling penting adalah adanya izin dari Menteri Kesehatan RI.

Saat ini tingkat kesehatan ibu dan anak di Indonesia masih jauh dari yang diharapkan, ditandai dengan masih tingginya AKI dan AKB. Target dari MDGs 
untuk jumlah AKI tahun 2015 adalah sebesar 102 per 100.000 kelahiran hidup dan target MDGs untuk AKB tahun 2015 sebesar 23 per 1000 kelahiran.

Angka Kematian Ibu sampai saat ini masih menjadi salah satu indikator yang digunakan untuk melihat besarnya derajat kesehatan pada perempuan. Angka kematian itu juga telah masuk menjadi target MDGs nomor 5. Yaitu, meningkatkan kesehatan ibu dan menurunkan angka kematian ibu hingga 3/4 sampai tahun 2015. Selain itu, target dari MDGs 5 ini mewujudkan akses kesehatan reproduksi bagi semua pada tahun 2015 .

Dari hasil survei yang dilakukan SDKI, presentase angka kematian ibu telah menunjukkan penurunan dari tahun ke tahun. Hanya saja, dari beberapa provinsi yang ada di Indonesia, Jawa Barat masih menjadi salah satu daerah dengan angka kematian ibu dan bayi yang paling tinggi. Untuk Tahun 2012, di Jawa Barat angka kematian ibu sebesar 804 kematian bayi sebanyak 4.803 , Jawa Tengah kematian ibu 668 dan kematian bayi 4.282, Jawa Timur kematian ibu 500 dan kematian bayi 4.128 Tahun 2013, angka kematian ibu di Jawa Barat 761 kematian bayi 4.107, Jawa Tengah kematian ibu 605 kematian bayi 4.112, Jawa Timur kematian ibu 627 dan kematian bayi 4.130 .

Berdasarkan data yang diperoleh dari Dinas Kesehatan Provinsi Jawa Barat terdapat tiga daerah di Jawa Barat penyumbang AKI dan AKB terbanyak pada tahun 2012 adalah Sukabumi jumlah AKI 76 dan AKB 524 kasus. Kedua, Bogor jumlah AKI 63 AKB 167 kasus. dan ketiga, Karawang jumlah AKI 47 AKB 158 kasus. Sedangkan untuk tahun 2013 Karawang menempati posisi ke dua dari penyumbang 
AKI dan AKB terbanyak yaitu AKI 64 kasus AKB 202 Kasus. Untuk daerah pertama Sukabumi sebanyak AKI 78 AKB 228 kasus, dan ketiga Bogor jumlah AKI 60 AKB 172 kasus.

Khususnya untuk Kabupaten Karawang jumlah AKI pada tahun 2013 sebanyak 64 kasus, dan untuk kasus AKB pada tahun 2013 sebanyak 187 kasus.

Kondisi di kabupaten Karawang menunjukan bahwa jumlah kematian ibu dan bayi masih tinggi dan merupakan penyumbang kedua kematian ibu dan bayi di Provinsi Jawa Barat. Sehingga perlu dilakukan sebuah terobosan yang inovatif dan kreatif dan mempunyai manfaat untuk menurunkan kematian ibu dan bayi.

Dalam rangka menurunkan AKI dan AKB perlu meningkatkan penyediaan akses terhadap pelayanan kesehatan berbasis masyarakat berdasarkan Rencana Pembangunan Jangka Menengah Daerah (RPJMD) Provinsi Jawa Barat tahun 20132018 dan Rencana Aksi Daerah Millenium Develloment Goals (RAD MDGs).

Untuk kelancaran dan efektivitas kegiatan penyediaan akses masyarakat perlu dibentuk Tim Koordinasi Program Penyelamatan Ibu dan Bayi Baru Lahir yang ditetapkan dengan Keputusan Gubernur Jawa Barat Nomor 441.8/Kep.1076Dinkes/2014 tentang “Tim Koordinasi Program Penyelamatan Ibu dan Bayi Baru Lahir”. Hal ini mengingat UU Nomor 11 tahun 1950 tentang Pembentukan Provinsi Jawa Barat, UU Nomor 32 tahun 2004 tentang Pemerintah Daerah, UU Nomor 36 tahun 2009 tentang Kesehatan, UU Nomor 11 tahun 2009 tentang Kesejahteraan Sosial, Peraturan pemerintah Nomor 38 tahun 2007 tentang Pembagian Urusan Pemerintah antara Pemerintah, Pemerintah Daerah Provinsi dan Pemerintah Daerah 
Kabupaten/Kota, Peraturan Daerah Provinsi Jawa Barat Nomor 10 tahun 2008 tentang Urusan Pemerintah Provinsi Jawa Barat, Peraturan Daerah Provinsi Jawa Barat Nomor 11 tahun 2010 tentang Penyelenggaraan Kesehatan, Peraturan Daerah Provinsi Jawa Barat Nomor 10 tahun 2012 tentang Penyelenggaraan Kesejahteran Sosial dan Peraturan Daerah Provinsi Jawa Barat Nomor 25 tahun 2013 tentang Rencana Pembangunan Jangka Menengah Daerah Provinsi Jawa Barat tahun 20132018.

Kementrian Kesehatan telah mengembangkan serangkaian model terobosan berbasis tekhnologi informasi dan komunikasi guna meningkatkan kualitas layanan komplikasi kegawatdaruratan ibu dan bayi serta meningkatkan efisiensi dan efektivitas sistem rujukan. Oleh sebab itu, Kementrian Kesehatan memberikan terobosan terbaru dalam penangananan kasus kematian ibu dan bayi yaitu dengan meluncurkan program EMAS (expanding, maternal, and newborn survival) dengan model sistem informasi yang dikembangkan meliputi : sistem informasi penguat dan pembelajaran informa (SIPPP), sistem informasi gerbang aspirasi pelayanan kesehatan publik (SIGAPKU), dan sistem informasi jejaring rujukan kegawatdaruratan ibu dan neonatal (SIJARIEMAS).

Sijariemas Kabupaten Karawang adalah sistem informasi komunikasi jejaring rujukan gawat darurat ibu dan bayi baru lahir, yang telah diintegrasikan dengan karawang sehat. Sijariemas dengan SMS Gateway 081212395555 Telepon 119/02678453243, Pin BBM 79003AFE, Web Karawangsehat.com, Facebook EMAS KARAWANG, dijaga oleh 8 Bidan Call Center yang tertalih, 2 petugas IT, Melayani 
24 jam 7 hari. Sejak diluncurkan tanggal 14 September 2013, telah merujuk lebih dari 3,638 kasus, dengan lebih dari 1124 tenaga kesehatan, 941 bidan telah terdaftar, melibatkan 50 Puskesmas dan 18 Rumah Sakit di Kabupaten Karawang. Oleh karena itu, uraian diatas membuat penulis merasa tertarik untuk melakukan penelitian dengan topik “ Kewajiban Bidan Dalam Menanggulangi Kematian Ibu dan Kematian Bayi di Hubungkan Dengan Undang-Undang Kesehatan No 36 Tahun 2009 tentang Kesehatan Juncto Keputusan Gubernur Jawa Barat Nomor 441.8/Kep.1076-Dinkes/2014 Tentang Tim Koordinasi Program Penyelamatan Ibu dan Bayi Baru Lahir".

\section{B. Identifikasi Masalah}

1. Bagaimana Kewajiban Bidan dalam Menanggulangi kematian ibu dan kematian bayi di hubungkan dengan UU Kesehatan Nomor 36 Tahun 2009 tentang Kesehatan Juncto Keputusan Gubernur Nomor 441.8/Kep.1076Dinkes/2014 tentang Tim Koordinasi Program Penyelamatan Ibu dan Bayi Baru Lahir?

2. Bagaimana Implementasi Keputusan Gubernur Nomor 441.8/Kep.1076Dinkes/2014 tentang Tim Koordinasi Program Penyelamatan Ibu dan Bayi Baru Lahir di Kabupaten Karawang? 


\section{Metode Penelitian}

Untuk mencapai tujuan tersebut dilakukan penelitian dengan menggunakan metode penelitian dengan pendekatan yuridis normative, yaitu dengan mengkaji atau menganalisis data skunder yang berupa bahan-bahan hukum sekunder dengan memahami hukum sebagai penelitian kepustakaan, yaitu penelitian terhadap data sekunder. Sifat penelitiannya adalah deskriptif analitis yang merupakan penelitian untuk menggambarkan dan menganalisa masalah yang ada dan termasuk dalam jenis penelitian kepustakaan yang akan di sajikan secara deskriptif dan penelitian deskriptif yaitu penelitian yang bertujuan untuk memberikan gambaran atau merumuskan masalah sesuai dengan keadaan atau fakta yang ada. Jenis datanya adalah data sekunder dan ditunjang dengan data primer. Tekhnik pengambilan data menggunakan studi dokumen dan wawancara. Tekhnik penentuan sample Porposive Sampling. pengambilan sample secara purposive didasarkan pada suatu pertimbangan tertentu yang dibuat oleh peneliti sendiri, berdasarkan ciri atau sifat-sifat populasi yang sudah diketahui sebelumnya. Tekhnik analisis data dianalisis secara normatif kualitatif dengan menafsirkan dan mengkontruksikan pernyataan yang terdapat dalam dokumen dan perundang-undangan. Normatif karena penelitian ini bertitik tolak terhadap perundang-undangan yang ada sebagai norma hukum positif, sedangkan kualitatif beratri menganalisis data yang bertitik tolak pada usaha penemuan asas-asas dan informasi terbaru. 


\section{PEMBAHASAN}

\section{Kewajiban Bidan Dalam Menanggulangi AKI dan AKB Juncto UU Nomor 36 Tahun 2009 tentang Kesehatan.}

Bidan adalah seorang yang telah diakui secara regular dalam program pendidikan kebidanan sebagaimana yang telah diakui skala yuridis, dimana ia ditempatkan dan telah menyelesaikan pendidikan kebidanan dan telah memperoleh kualifikasi serta terdaftar disahkan dan memperoleh izin melaksanakan praktik kebidanan. Kebidanan adalah ilmu yang terbentuk dari sintesa berbagai disiplin ilmu yang terkait dengan pelayanan kebidanan meliputi ilmu kedokteran, ilmu keperawatan, ilmu sosial, ilmu perilaku, ilmu budaya, ilmu kesehatan masyarakat dan ilmu manajemen kebidanan, untuk dapat memberikan pelayanan kepada ibu di dalam masa pra konsepsi, hamil, bersalin, postpartum, dan bayi baru lahir.

Bidan sebagai anggota profesi. Sebagai anggota profesi, bidan mempunyai ciri khas yang khusus. Sebagai pelayan profesional yang notabene merupakan bagian integral dari pelayanan kesehatan. Bidan mempunyai tugas yang sangat unik, yaitu:

a. Selalu mengedepankan fungsi ibu sebagai pendidik bagi anak-anaknya.

b. Memiliki kode etik dengan serangkaian pengetahuan ilmiah yang didapat melalui proses pendidikan dan jenjang tertentu.

c. Keberadaan bidan diakui memiliki organisasi profesi yang bertugas meningkatkan mutu pelayanan kepada masyarakat.

d. Anggotanya menerima jasa atas pelayanan yang dilakukan dengan tetap memegang teguh kode etik profesi. 
Hal tersebut akan terus diupayakan oleh para bidan sehubungan dengan anggota profesi yang harus memberikan pelayanan profesional. Tentunya harus diimbangi dengan kesempatan memperoleh pendidikan lanjutan, pelatihan, dan selalu berpartisipasi aktif dalam pelayanan kesehatan.

Fungsi dan peran bidan di Desa bila dibandingkan dengan tenaga kesehatan lain di daerah perkotaan bisa dikatakan lima kali lebih berat. Selain menghadapi kendala yang besar dalam hal fasilitas, tranportasi, ketersediaan obat dan sarana penunjang lain. Para bidan tetap dengan ikhlas berjuang dan bertugas menjalankan profesinya. Disisi lain mereka harus pula memenuhi kebutuhan bagi dirinya. Sedangkan tuntutan terhadap pelayanan kesehatan ibu dan anak mutlak dan harus dipenuhi. Filosofi dasarnya adalah, apabila seorang ibu baik dan sehat, sehat pula sang anak. Anak merupakan aset bangsa yang harus dipelihara dan dididik.

Peranan bidan yang tampak nyata adalah sebagai role model masyarakat, sebagai anggota masyarakat, konselor, motivator, dan inovator di daerah terpencil. Tentunya kompetensi seperti ini yang akan dikembangkan lebih lanjut melalui pendidikan dan pelatihan bagi para bidan. Peranan yang harus dilihat sebagai "main idea" untuk membentuk sebuah peradaban dan tatanan pelayanan kesehatan. Tuntutan profesional diseimbangkan dengan kesejahteraan bidan diwilayah kerjanya.

Bidan memiliki peran historis yang cukup kuat dalam masalah kesehatan ibu dan anak di Indonesia karena sebagian besar kelahiran di tanah air dibantu oleh tangantangan trampil dan terdidik dari seorang bidan. Posisi geografis serta sebaran penduduk membuat bidan dituntut untuk semakin berperan tidak hanya dalam 
pertolongan persalinan namun juga edukasi gizi dan kesehatan terhadap masyarakat khususnya ibu-ibu dalam persiapan, selama masa kehamilan, persalinan, nifas dan bayi baru lahir.

Peran bidan sangat dibutuhkan dalam menangani masalah tingginya angka kematian ibu (AKI) dan angka kematian bayi (AKB), akan tetapi peraturan yang menetapkan tentang peran bidan sebagai penolong utama dalam penurunan AKI dan AKB belum di tetapkan secara spesifik di dalam UU Kesehatan baik UU Kesehatan Nomor 36 tahun 2009 tentang Kesehatan ataupun UU Kesehatan Nomor 36 tahun 2014 tentang Tenaga Kesehatan.

Di dalam UU Nomor 36 tahun 2009 tentang Kesehatan hanya membahas tentang Kesehatan ibu, bayi, anak dan balita yaitu pada pasal 126 dan pasal 131.

Pasal 126 : upaya kesehatan ibu harus ditujukan untuk menjaga kesehatan ibu sehingga mampu melahirkan generasi yang sehat dan berkualitas serta mengurangi angka kematian ibu.

Pasal 131 : upaya pemeliharan kesehatan bayi dan anak harus ditujukan untuk mempersiapkan generasi yang akan datang yang sehat, cerdas dan berkualitas serta untuk menurunkan angka kematian bayi dan anak.

Sedangkan untuk UU Kesehatan Nomor 36 tahun 2014 tentang tenaga kesehatan tidak ada sama sekali yang membahas dan menetapkan peraturan tentang peran bidan dan ataupun Kesehatan ibu, bayi dan anak. UU tersebut lebih menitik beratkan terhadap kualifikasi tenaga kesehatan.

Registrasi Pasal 44

(1) Setiap Tenaga Kesehatan yang menjalankan praktik wajib memiliki STR.

(2) STR sebagaimana dimaksud pada ayat (1) diberikan oleh konsil masing-masing Tenaga Kesehatan

(3) setelah memenuhi persyaratan.

(4) Persyaratan sebagaimana dimaksud pada ayat (2) meliputi: 
a. memiliki ijazah pendidikan di bidang kesehatan;

b. memiliki Sertifikat Kompetensi atau Sertifikat Profesi;

c. memiliki surat keterangan sehat fisik dan mental;

d. memiliki surat pernyataan telah mengucapkan sumpah/janji profesi; dan

e. membuat pernyataan mematuhi dan melaksanakan ketentuan etika profesi.

(5) STR berlaku selama 5 (lima) tahun dan dapat diregistrasi ulang setelah memenuhi persyaratan.

(6) Persyaratan untuk Registrasi ulang sebagaimana dimaksud pada ayat (4) meliputi:

a. memiliki STR lama;

b. memiliki Sertifikat Kompetensi atau Sertifikat Profesi;

c. memiliki surat keterangan sehat fisik dan mental;

d. membuat pernyataan mematuhi dan melaksanakan ketentuan etika profesi;

e. telah mengabdikan diri sebagai tenaga profesi atau vokasi di bidangnya; dan

f. memenuhi kecukupan dalam kegiatan pelayanan, pendidikan, pelatihan, dan/atau kegiatan ilmiah lainnya.

Pasal 45

Ketentuan lebih lanjut mengenai tata cara Registrasi dan Registrasi ulang sebagaimana dimaksud dalam Pasal 44 diatur dengan Peraturan Konsil masingmasing Tenaga Kesehatan.

Peran adalah salah satu fungsi yang dimiliki oleh seseorang, begitupun dengan bidan. Bidan merupakan salah satu tenaga kesehatan yang memiliki posisi penting dan strategis terutama dalam penurunan angka kematian ibu dan kematian bayi. Bidan memberikan pelayanan kebidanan yang berkesinambungan dan paripurna, berfokus pada aspek pencegahan, promosi dengan berlandasan kemitraan dan pemberdayaan masyarakat bersama-sama dengan tenaga kesehatan lainnya untuk senantiasa siap melayaani siapa saja yang membutuhkannya, kapan dan dimanapun dia berada. Untuk menjamin kualitas tersebut maka diperlukan suatu kualitas pelayanan kesehatan yang lebih efektif dan efesien yaitu dengan diadakannya program SijariEMAS yang berfokus terhadap penanganan kegawatdarurata ibu dan bayi baru lahir sehingga dapat membantu menurunkan kematian ibu dan kematian 
bayi khususnya di Kabupaten Karawang hal tersebut dilakukan untuk melakukan segala tindakan dan asuhan yang diberikan dalam seluruh aspek pengabdian profesinya kepada individu, keluarga dan masyarakat. Baik dari aspek input, proses dan output. Dengan bertujuan menjamin memberikan pelayanan yang aman dan berkualitas. Hal ini sebagaimana yang tercantum dalam UU Kesehatan Nomor 36 tahun 2009 pasal 4 ayat (1) setiap orang berhak mempunyai hak yang sama dalam memperoleh akses atas sumber daya di bidang kesehatan. ayat (2) setiap orang mempunyai hak dalam memperoleh pelayanan kesehatan yang aman, bermutu dan terjangkau. Pembangunan kesehatan harus memperhatikan berbagai asas yang memberikan arah pembangunan kesehatan dan dilaksanakan melalui upaya kesehatan, dengan mempertimbangkan asas kemanusiaan, asas keseimbangan, asas kemanfaatan, asas perlindungan, asas keadilan, asas penghormatan hak dan kewajiban, asas gender dan nondiskriminasi dan asas norma agama.

Sehubungan dengan peningkatan pelayanan kesehatan yang bertujuan untuk menekan jumlah kematian ibu dan kematian bayi, upaya lain yang dilakukan oleh pemerintah dan pemerintah daerah yaitu melakukan terobosan terbaru dengan meluncurkan program SijariEMAS yaitu program yang berfokus kepada penanganan kegawatdaruratan ibu dan bayi baru lahir. Salah satu yang dapat dihubungkan dengan peran bidan dalam menanggulangi kematian ibu dan kematian bayi yaitu dengan ikut sertanya/ berpartisipasi profesi bidan dengan program SijariEMAS, hal tersebut merupakan peranan bidan sebagai pelaksana, pengelola, pendidik dan peneliti. Yang pada intinya bahwa dengan turut sertanya bidan melakukan kolaborasi dengan 
progam SijariEMAS bidan tersebut telah memberikan asuhan kebidanan dan pelayanan kebidanan yang berkesinambungan, asuhan kebidanan yang berupaya pada asuhan promotif, preventif, kuratif dan rehabilitatif. Serta dengan ikut bergabungnya bidan dalam program tersebut, bidan telah melakukan kolaborasi dengan tim atau petugas kesehatan lainnya untuk bersama-sama memberikan kontribusi peningkatan pelayanan kesehatan berbasis masyarakat dan untuk masyarakat.

\section{Implementasi Keputusan Gubernur Nomor 441.8/Kep.1076-Dinkes/2014 tentang Tim Koordinasi Program Penyelamatan Ibu dan Bayi Baru Lahir di Kabupaten Karawang.}

Sistem informasi penguatan pembelajaran \& performa (SIPPP) merupakan sistem pembelajaran jarak jauh dan 2 arah berbasis tekhnologi SMS dan internet yang didesain untuk memfasilitasi para bidan maupun tenaga kesehatan lainnya untuk mendaptkan seangkaian update pengetahuan terkait dengan tata laksana komplikasi maternal dan neonatal yang terbukti mempunyai dampak besar dalam penurunan AKI dan AKB tersebut dimanapun dan kapanpun.

Selain mengirimkan serangkaian SMS yang berisi kasus-kasus yang sering terjadi dan dihadapi oleh para bidan terkait komplikasi maternal dan neonatal, system informasi ini juga akan mengirimkan serangkaian kuis yang didesain untuk dapat mengukur tingkat pemahaman bidan terhadap tata laksana komplikasi tersebut. 
Setiap jawaban secara otomatis akan dibalas yang berisi informasi maupun petunjuk tambahan terkait dengan tata lakasana tersebut.

Sistem informasi ini juga dilengkapi dengan serangkaian fungsi pengelolaan data dan informasi yang dapat menjadi sebuah alat pendukung pengambil keputusan bagi para pemangku kebijakan untuk dapat memberikan intervensi lanjutan seperti pelatihan lanjutan ataupun penyedia fasilitas.

Sistem Informasi Jejaring Rujukan Ibu dan Neonatus (SIJARIEMAS) merupakan terobosan terbaru dan merupakan yang pertama yang khusus dikembangkan guna meningkatkan efesiensi dan efektivitas system rujukan maternal dan neonatal. Sistem informasi ini didesain untuk mempercepat proses pertukaran data dan informasi maupun komunikasi dalam rujukan gawat darurat maternal dan neonatal antara bidan, puskesmas hingga rumas sakit.

Dengan sistem informasi ini bidan perujuk diwajibkan untuk mengirimkan SMS rujukan ataupun melakukan panggilan telephone ke nomor akses sistem yang secara otomatis akan mengelola dan meneruskan informasi tersebut ke fasilitas penerima rujukan (PONED atau RS) guna memastikan bahwa fasilitas penerima rujukan telah siap siaga dalam menerima dan menangani pasien yang dirujuk tersebut. Dengan demikian pasien rujukan mendapat kepastian PONED/RS yang dapat menjadi tujuan rujukan dan kepastian adanya sarana dan prasarana serta tenaga medis yang mampu memberikan pelayanan yang dibutuhkan secara berkualitas.

Sesuai standar, sistem juga akan secara pintar merekomendasikan tempat rujukan terdekat dan tersiap untuk menerima pasien tersebut. Untuk para pengambil 
keputusan, sistem ini akan memberikann informasi yang realtime terkait informasi rujukan seperti waktu respon/respontime, jenis dan penyebab komplikasi dll.

Program SijariEMAS ini telah mengikutsertakan 18 RS yang terdapat di Karwang baik RSUD dan RS Swasta. Maksud dari 18 RS yang turut serta yaitu : dari 18 RS terdapat 3 RS pendamping utama dalam sistem rujukan SijariEMAS yaitu RS Citra Sari Husada, Rs Djoko Pramono dan RSUD. Disamping RS pendamping utama terdapat RS pendamping ke 2 yang ikut serta dalam dengan progam SijariEMAS, terdapat 4 RS yang bergabung diantaranya adalah : RSU Puri Asih, RS Islam Karawang, RS Rosella, dan RS Mitra Family. Selebihnya adalah RS dampingan ke 3 dalam rujukan.

Karawang memiliki dua Kabupaten yaitu Kabupaten Karwang Barat dan Karawang timur, Karawang Barat memiliki RS Djoko Pramono dan RSUD untuk RS utama Rujukan, sedangkan untuk Karawang Timur RS Citra Sari Husada.

\section{PERBANDINGAN JUMLAH RUJUKAN MELALUI CALL CENTER SIJARIEMAS DENGAN JUMLAH PASIEN DI 3 RS SEPTEMBER 2013 - OKTOBER 2014}

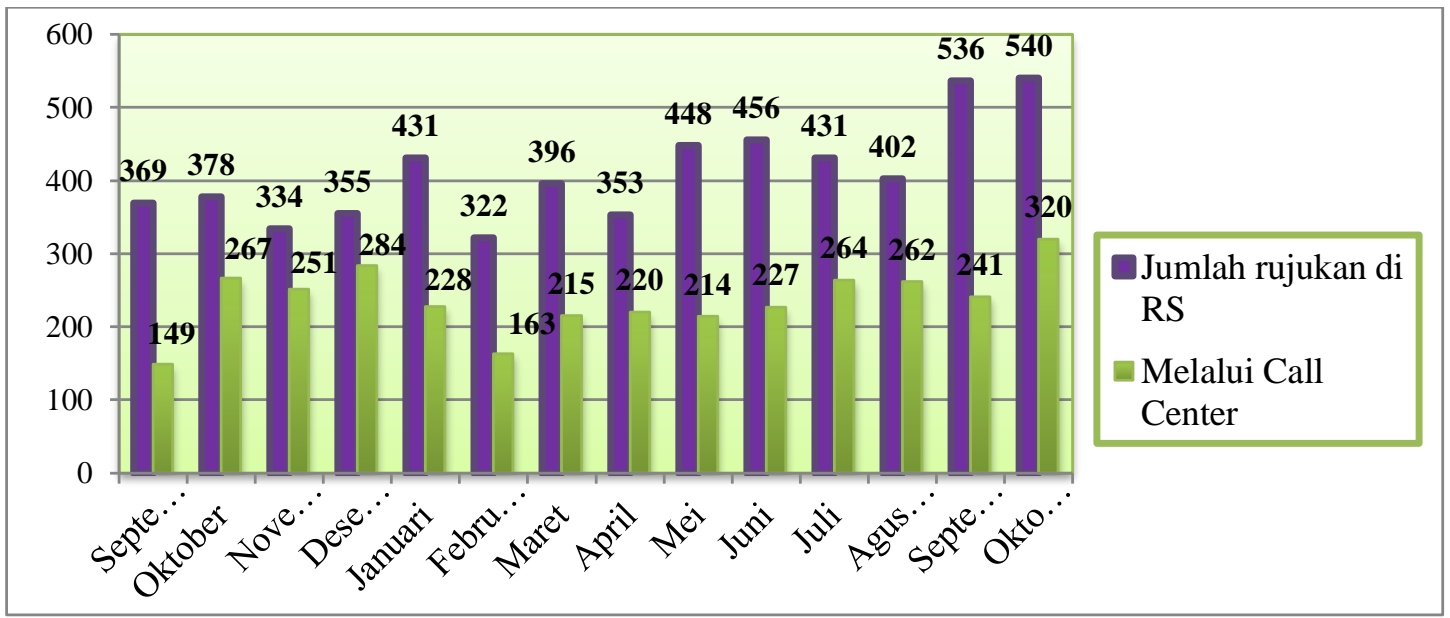


Perbandingan adalah suatu pernyataan untuk membandingkan suatu besaran dengan besaran lain.

Dari perbandingan jumlah kasus rujukan ke tiga RS dampingan SijariEMAS yaitu RSUD, RS Citra Sari Husada, RS Djoko Pramono keseluruhan kasus rujukan terdapat 5751 kasus, sedangkan untuk kasus rujukan yang menggunakan program SijariEMAS terdapat 3305. Lebih dari setengahnya kasus rujukan yang terdapat di RSUD/RS Swasta menggunakan program SijariEMAS, hal tersebut dapat disimpulkan bahwa program SijariEMAS ini memberikan manfaat bagi RS. Sesuai dengan asas manfaat yang diharapkan dari program ini. Manfaat SijariEMAS bagi RS diantaranya adalah :

a. Memberi informasi sejak dini kondisi pasien yang akan dirujuk.

b. Memberi waktu bagi RS untuk menyiapkan sarana prasarana, tenaga, perlengkapan, peralatan, obat dst

c. Meningkatkan komunikasi yang jelas, tercatat, sistematis dengan puskesmas/bidan secara murah, mudah dan handal.

d. Sebagian media untuk berjejaring berkolaborasi antar RS atau RS-Puskesmas.

e. Merekam proses pemberian pelayanan.

f. Menyediakan data untuk evaluasi rujukan (jumlah) yang dirujuk.

\section{g. Meningkatkan citra RS}

Dengan adanya Program SijariEMAS jumlah kasus AKI dan AKB berhasil diturunkan, dari bulan September 2013-2014, jumlah AKI yang berhasil diturunkan 33\% yaitu sebanyak 64 kasus 2013 menjadi 37 kasus 2014. Untuk jumlah kasus AKB diturunkan sebanyak 55\% dari 187 kasus 2013, menjadi 135 kasus 2014. 
Program SijariEMAS selain memiliki keunggulan dalam keberhasilannya menurunkan kematian ibu dan kematian bayi, program tersebut juga memiliki kekurangan. Hasil dari wawancara yang dilakukan dengan tenaga kesehatan yang bekerja pada bagian sektor penanganan program SijariEMAS didapatkan kekurangan dari program tersebut adalah sebagai berikut :

a. Terbatasnya RS yang memiliki program SijariEMAS karena keterbatasan biaya untuk mempersiapakn perlatan yang dibutuhkan untuk penyediaan program SijariEMAS, karena bagi RS yang ingin memiliki fasilitas Program SijariEMAS harus mengeluarkan anggaran pribadi dari RS, sedangkan Dinas Kesehatan hanya memfasilitasi server nya saja.

b. Keterbatasan dalam SDM, di Dinas sendiri SDM yang dimiliki yaitu sebanyak 8 bidan yang terbagi menjadi 3 shif kerja, yaitu shif pagi dari jam 07.0014.00, shif 2 dari jam 14.00-21.00 dan shif 3 dari jam 21.00-07.00. Untuk tekhnik IT hanya memiliki 2, dan itu pun tidak bertugas selama 24 jam, tekhnik IT hanya di panggil ketika server mengalami gangguan saja, sedangkan tidak ada yang akan mengetahui kapan server internet, atau program tersebut error dan atau dalam gangguan.

c. Keterbatasan ruang rawat untuk bayi dan balita yaitu NICU, ruang rawat NICU hanya dimiliki oleh RS Citra Sari Husada, RSUD dan RSU Karya Husada. Hal tersebut dapat berakibat fatal, karena apabila suatu ketika ruang NICU di 3 RS tersebut penuh maka akan terdapat kesulitan dalam merujuk pasien bayi. Dan hal tersebut dapat menyebabkan 3T yaitu : terlambat 
mendapatkan penanganan, terlambat mengambil keputusan dan terlambat dalam transfortasi.

d. Ganguan pada jaringan internet, petugas Call Center mengeluhkan jaringan yang terkadang error.

\section{DAFTAR PUSTAKA}

\section{A. BUKU-BUKU}

Abdul Bari Saifusin, Ilmu Kebidanan, YPBSP, Jakarta, 2008.

Ahmad husaini, CMI (cara memberi Intruksi), ASEN Cipta Kreatif , Jakarta, 2010

Anik Maryini, Ilmu Kesehatan dalam Kebidanan, Muha Medika, 2009.

Anik Maryinani \& Yulianingsih, Asuhan Kegawatdaruratan dalam Kebidanan, Salemba Medika, Jakarta 2009. Hlm 31.

Ary Sulistyawati, Asuhan Kebidanan dan ibu bersalin, Salemba Medika, Jakarta, 2005., 2000.

Burhan Ashofa, Metode Penelitian Hukum, Rieneka Cipta, Jakarta, 2002.

Bahder Johan Nasution, Hukum Kesehatan Pertanggungjawaban Dokter, Rieneka Cipta, Jakarta, 2005.

Diyah Widyatun, Asuhan Kebidanan dan Manajemen Kebidanan, Rieneka Cipta, Jakarta,2012.

Dwana Estiwidani, Niken Meliani, Hesty Widynaingsih, dkk, Konsep Kebidanan, Rieneka Cipta, Jakarta, 2008. 
Soekidjo Notoatmodjo, Metodologi Penelitian Kesehatan, Rineka Cipta, Jakarta,2005.

Soejono Soekanto, Pengantar Penelitian Hukum, UI Press, Jakarta, 2007.

Soejono Soekanto dan Sri Madmudji, Penelitian Hukum Normatif, Suatu Tinjauan Singkat, Rajawali, Jakarta, 1985.

Sofyan Dahlan, Malpraktek Pencegahan dan Penanganan Kasus Dugaan Malpratek, BP UNDIP, Semarang, 2006.

Soewono, Batas Pertanggungjaaban Dokter dalam Malpraktek Medis, Rieneka Cipta, Jakarta, 2005.

Szass dan Hollender dalam Klien, Citra, Peran dan Perilaku oleh Benyamin Lumneta, Kanisius, 1998.

Yanti dan Nurul Eko, Etika Profesi kebidanan, Pustaka Rihama, Yogyakarta, 2010.

Yusuf Sofie, Perlindungan Konsumen Instrumen-Instrumen Hukumnya, Citra Adiya Bhakti Cet 3, Bandung, 2009.

\section{B. KITAB UNDANG-UNDANG}

Undang-Undang Kesehatan Nomor 36 Tahun 2009 tentang Kesehatan

Peraturan Menteri Kesehatan Nomor 369 Tahun 2007 tentang Standar Profesi Bidan

Peraturan Menteri Kesehatan Nomor 1464 Tahun 2010 tentang Izin dan Penyelenggaraan Praktik Bidan.

Pearuran Daerah Karawang Nomor 441.8 tentang Tim Kordinasi Program Penyelamatan Kematian Ibu dan Bayi 